\title{
Egg quality detection system using fuzzy logic method
}

\section{Ikbar Mahesa*1, Aji Gautama Putrada², Maman Abdurohman ${ }^{3}$}

Telkom University/School of Computing ${ }^{1,2,3}$

\author{
Article Info \\ Keywords: \\ Accuracy, Realtime, Fuzzy Logic, Egg, \\ Internet of Things
}

\section{Article history:}

Received 16 May 2019

Revised 4 July 2019

Accepted 9 July 2019

Published 30 July 2019

\section{Cite:}

Mahesa, I., Putrada, A., \& Abdurohman, M. (2019). Egg Quality Detection System Using Fuzzy Logic Method. Kinetik: Game

Technology, Information System, Computer

Network, Computing, Electronics, and Control,

4(3).

doi:http://dx.doi.org/10.22219/kinetik.v4i3.839

${ }^{*}$ Corresponding author.

Ikbar Mahesa

E-mail address:

barmahesa@student.telkomuniversity.ac.id

\begin{abstract}
Determining the quality of eggs in general is used by placing eggs on a flashlight. The detection system is very necessary to determine good egg quality or rotten eggs, so that the conditions of the eggs can be known by the chicken farm company and then will be sold to the community. This egg detecting system utilizes several sensor devices that are combined. The sensor used to detect the quality of eggs is a light sensor and a heavy sensor by connected with a microcontroller. So that there is no ambiguity towards the decision making of good egg or rotten eggs, then processing the data is obtained from these sensors using Fuzzy Logic and Firebase methods in real time as data storage media, and actuators will distribute or separate good eggs or the rotten eggs one. With the development of technology now, we can use the Internet of Things (IoT) technology, one of the systems check the quality of eggs which are good or not good. This system is built using a microcontroller to coordinate the running of the system using the Fuzzy Logic Method that applies inside. Final information is obtained on the form of egg quality in real time. The test results were carried out using the Fuzzy Logic method and obtained $95 \%$ results from 20 eggs and had 1 wrong egg. When using system hardware without using the fuzzy logic method on the microcontroller that using only a light sensor and a heavy sensor it produces a result of $75 \%$ from 20 eggs and had 5 wrong eggs. Using the egg detection optimization method can be increased up to $20 \%$.
\end{abstract}

\section{Introduction}

Eggs are food products that are livestock that have a good source of protein, eggs are rich in iron and lime. Egg yolks provide fat-soluble vitamins. Eggs taste delicious, are easily digested and have high nutrition. In addition, eggs are easy to get anywhere and have a relatively cheap price. Eggs are also widely used by people for side dishes, cakes and others [1]. Nevertheless eggs can experience a decrease in quality because they are influenced by microbes, physical damage, evaporation of water and gases such as carbon dioxide, ammonia, nitrogen and hydrogen sulfide from the egg. The longer the egg is stored, the evaporation will make the egg not good or rotten. Can be seen from the yolk index, albumen index and egg $\mathrm{pH}$ by $(\mathrm{P}<0.5)$ [2], [3], [4].

Eggs that are sold are not necessarily good quality because they are too long to store eggs and the storage process is not in accordance with the place. eggs sorting is done by looking into the sun or with a flashlight, using manual methods for eggs sorting had very long time process and the results can not to be accurate because many factors that affect the eggs sorting such as poor vision, with the number of eggs which is not a few to do checking manually. If the egg is overlaid with the sun or with a flashlight is bright, the condition is still good, if it does not look bright or dark, the egg is not good because it is contained in the egg which inhibits lighting like a mature egg [2], [5], [6].

One of the emerging technologies, which is a trend currently, that is the Internet of Things (IOT). Literally, this technology will connect everything through the Internet. Some applications have been developed based on loT platforms such as [7], [8], [9]. In the same way, loT can be a solution for sending data from the field to the server via the Internet realtime or there is no delay in sending data [10]. By using loT technology, detecting eggs can be monitored by using a smart phone over long distances or not be at the location of egg checking [11]. To see the results of how many eggs are good and how many eggs are rotten, the solution needed is to design a system to determine or detect eggs that are good or rotten by applying the Fuzzy Logic method.

Fuzzy logic is a logic that has a value of obscurity or similarity between right or wrong. In classical logic it can be expressed in binary ( 0 or 1 , yes or no). In making a device that can detect eggs which are good or not by using the Fuzzy Logic method, to read process from light sensors and heavy sensors. The value has been obtained will be distributed or separate good eggs or poor eggs [12], [13], [14]. Fuzzy logic that is used by mamdani, application function application uses MIN-MAX. The output generated from the output has been processed through the sensor as input. Output inference is a fuzzy number which is determined from the value of a particular crips as output [15], [16].

Cite: Mahesa, I., Putrada, A. G., \& Abdurohman, M. (2019). Egg Quality Detection System Using Fuzzy Logic Method. Kinetik: Game Technology, Information System, Computer Network, Computing, Electronics, and Control, 4(3). Kinetik: Game Technology, Information System, Computer Network, Computing, Electronics, and Control, 4(3). doi:http://dx.doi.org/10.22219/kinetik.v4i3.839 
The egg quality detection system uses a NodeMCU microcontroller equipped with an LDR sensor and loadcell weight sensor. The LDR sensor or light sensor that affects light will decrease its resistance and vice versa if there is no light entering or regarding the LDR sensor then the resistance rises or is high [17]. Whereas for loadcell sensors for pressure or force can measure of changes that affect the strain as electrical signals, because effective changes occur at the electrical wire resistance load. A loadcell will give the output voltage of the change in resistance that occurs due to a change in the position of the load buffer, so that the change must be entered into the amplifier [18]. Based on the background, there are identification problems such as how to implement a smart egg quality detection system and how to analyze the fuzzy logic performance system in detecting egg quality. In identifying problems that have been explained, that there are limitations to the problem in research such as the design of the tool. Tests on the egg quality detection system are carried out on the prototype. In addition, the test uses only chicken eggs. The findings of this paper are processes using fuzzy logic which functions in determining decisions by utilizing data from sensors.

\section{Research Method}

This research is a continuation or update from previous research, where this study focuses on making egg quality detection devices and using the Internet of Things (IOT). The previous paper discussed the design of egg rot detectors using the fuzzy logic method based on the Arduino nano 328 microcontroller using light serers and MQ2 gas sensors [19]. But the journal only implements the detection of rotten eggs and does not use Internet of Things (lot). Another paper discussed the egg quality detection system to detect new egg conditions from chickens. Journal system design uses the fuzzy logic method in determining the arrangement scheme in the sensor related to the indication. Egg quality and designing an automatic control system to detect the quality of eggs. Of several factors that affect the quality of the eggs such as humidity, temperature and preservation conditions. Automatic checks consist of mechanical and electrical models. Eggs are divided into four classes according to volume and weight. The volume and weight can be calculated to determine the result. To detect it using light that has $6 \mathrm{~V}, 0.5 \mathrm{~A}$. and captured by a light sensor to determine it. Automatic system control for detection based on DSP. In eggs that are less good, many factors affect such as cracked and durable eggs which will affect the quality of the eggs that will be sold, usually preserved by having thin and brittle egg shells. Eggs that are preserved will be attacked by bacteria and reproduction of bacteria causes eggs to rot and will spread to other eggs with conditions that are still good [2], [6], [20].

The egg detection system serves to detect egg quality. On the system device there is a heavy sensor and light sensor that will provide input values to the NodeMCU ESP8266 which will be processed using the fuzzy logic method. the output value obtained in the form of a final decision on the eggs that will be displayed on the smartphone through firebase.

In Figure 1 there are two micro controllers, which are Arduino and NodeMCU ESP8266 which are interconnected. In this system there are sensors and acuators, for heavy sensors, light sensors and infrared connected to Arduino. The data obtained will be sent to NodeMCU in serial communication and directly processed using the fuzzy logic method, then sent to firebase and will appear in the application.

Figure 2. the system is detecting the quality of eggs built requires one pipe or which can be passed by the egg. In the pipe where the egg passes and inside the pipe there are two sensors, namely Load Cell, LDR. The heavy sensor device, the light used in this system to determine the quality of the egg and the results of the two sensors will regulate the movement of an Akuator, which is a servo, is it a good or not good egg and is placed in the right or left box and each side of the egg quality results in an infrared sensor to count the passing eggs.

The system detects egg quality, the device can detect good or rotten egg quality and is in accordance with the original in the form of detecting using heavy and light sensors, which can be able to process the sensor input values using the fuzzy logic method, users can monitor data from the application. There are 2 Arduino and NodeMCU microcontrollers, for Arduino its functions as an input data path and it sent serial communication to the NodeMCU and will be moved using the actuator to send simultaneously to the application via Firebase. In the system of detecting egg quality, there is a system flow diagram that shows how the system works with a series of processes in stages Figure 3 .

In the system process flow in Figure 3 the system runs starting with a microcontroller that has been installed with other hardware. It is synchronized to wifi then the sensors contained in arduino read the LDR sensor and heavy sensor values. The data that has been obtained then collected in NodeMCU and then be processed using the fuzzy logic method. And then the data is sent to firebase, if it has been failed to detect, it will be re-read. If it has been detected, it will be saved in Firebase and will be displayed in the application.

In Table 1 describes the value of the category and fuzzy set which becomes a reference to determine the value generated by the system. This value is determined by the range according to the results of the readings from the sensors used, namely Loadcell for weight and LDR for light.

(c) 2019 The Authors. Published by Universitas Muhammadiyah Malang

This is an open access article under the CC BY SA license. (https://creativecommons.org/licenses/by-sa/4.0/) 

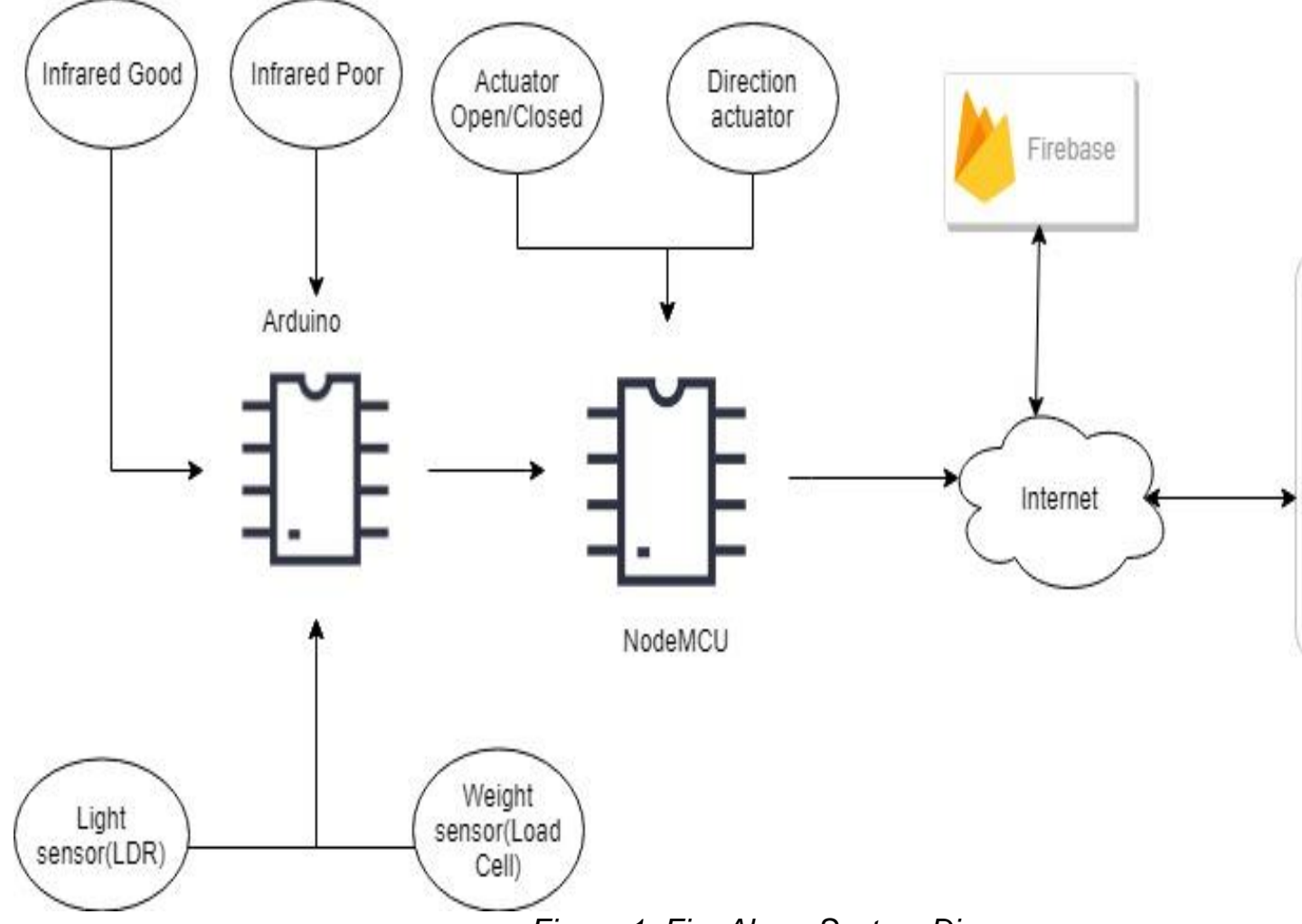

NodeMCU

Figure 1. Fire Alarm System Diagram

\section{Good Egg}

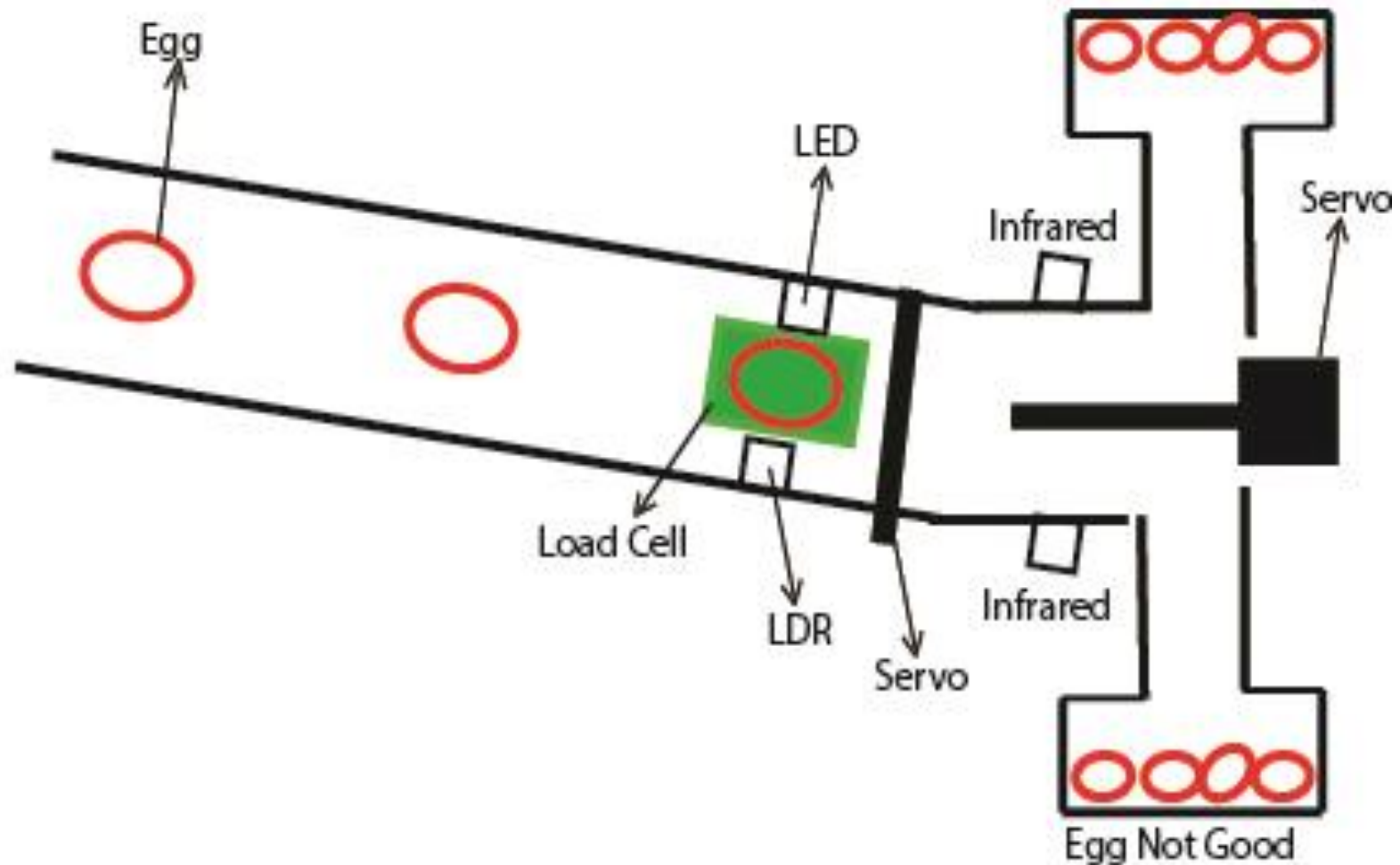

Figure 2. General Description Of The System 


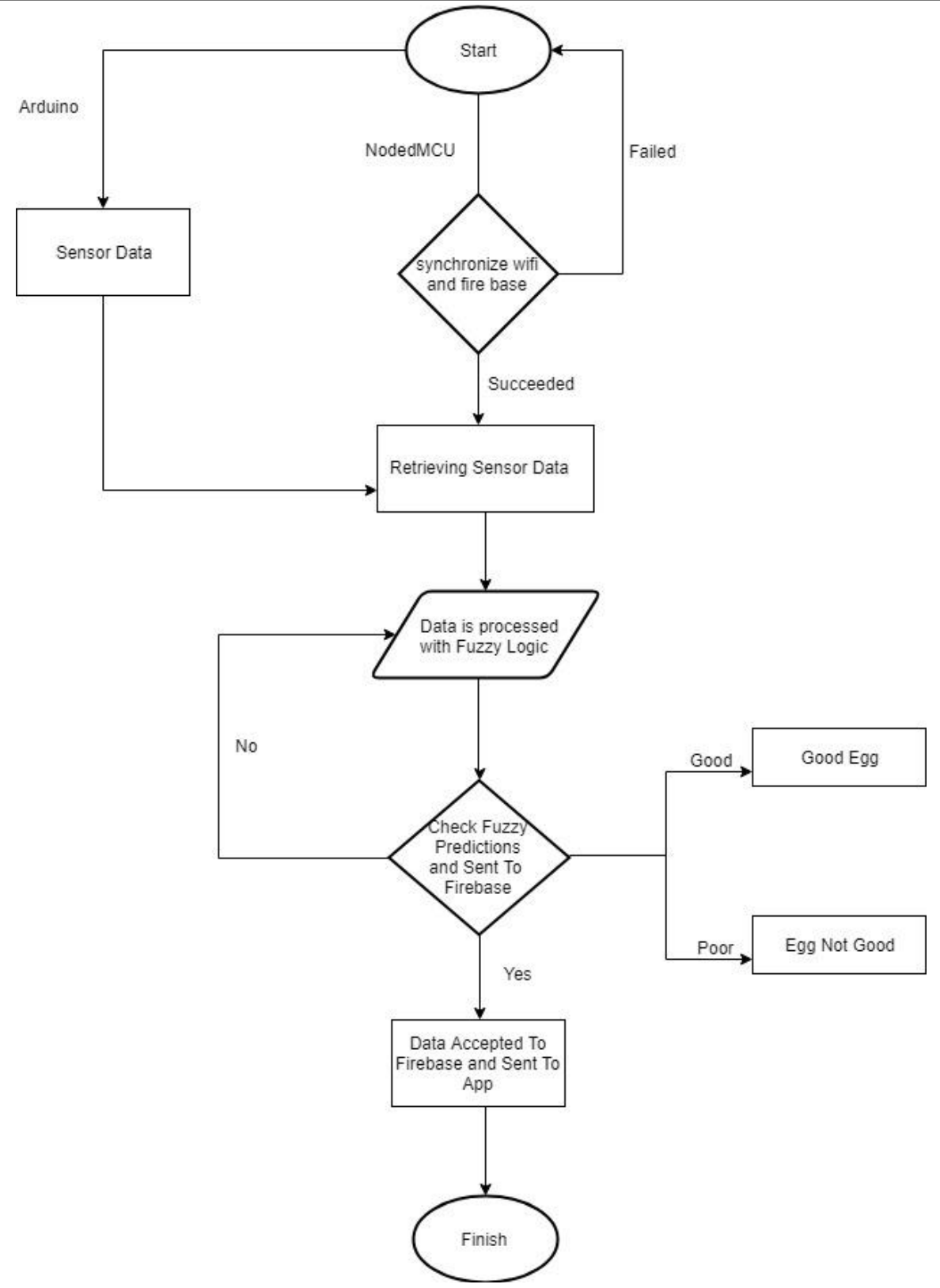

Figure 3. Flow Diagram

Table 1. Model Fuzzy Inference Rule

\begin{tabular}{llll}
\hline Type & Name & Category & Fuzzy Set \\
\hline \multirow{2}{*}{ Eata Input } & & Light & $(0,0,30,40)$ \\
& & Normal & $(30,40,50,60)$ \\
& & Heavy & $(50,60,70,80)$ \\
& \multirow{3}{*}{ Egg Light } & Nice & $(0,0,960,970)$ \\
& & Medium & $(960,970,980,990)$ \\
Data Output & \multirow{2}{*}{ Results } & Bad & $(980,990,1000,1010)$ \\
\hline
\end{tabular}

From fuzzy rule that has been determined, then get the value that becomes the limit on the system that is built. In Figure 4 describes fuzzy rule for the value of light in eggs. The egg light variable consists of 3 fuzzy sets which are good, medium and bad. The purpose of grouping is to find out the light conditions that penetrate the eggs. 


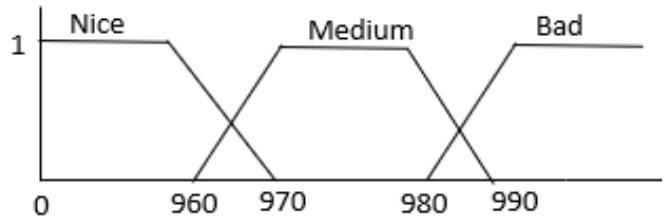

Figure 4. Egg Light Membership Function

In Figure 5, it explains fuzzy rule regarding the weight value of eggs in the main egg weight variable consisting of 3 fuzzy sets, namely light, normal and heavy. The purpose of the grouping is to find out the severe conditions in the egg.

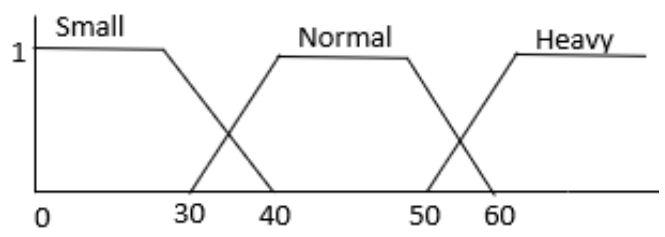

Figure 5. Egg Weight Function Membership

In Figure 6 describes fuzzy rule regarding the final value obtained. the result variable consists of 2 fuzzy sets which are good and poor. The purpose of grouping is to find out the final condition in the egg and will move the servo from the results obtained.

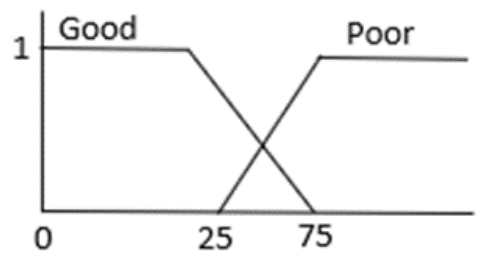

Figure 6. Function Membership Function

The built-in rule is used for controlling servo or making decisions on the results of egg quality: In the design of this system there are nine fuzzy rules that have been determined, as follows:

1. IF Weight Egg $=$ Small and Light Egg $=$ Nice THEN Results $=$ Good

2. IF Weight Egg $=$ Small and Light Egg $=$ Medium THEN Results $=$ Good

3. IF Weight Egg $=$ Small and Light Egg $=$ Bad THEN Results $=$ Poor

4. IF Weight Egg $=$ Normal and Light Egg $=$ Nice THEN Results $=$ Good

5. IF Weight Egg $=$ Normal and Light Egg $=$ Medium THEN Results $=$ Good

6. IF Weight Egg $=$ Normal and Light Egg $=$ Bad THEN Results $=$ Poor

7. IF Weight Egg $=$ Heavy and Light Egg $=$ Nice THEN Results $=$ Good

8. IF Weight Egg $=$ Heavy and Light Egg $=$ Medium THEN Results $=$ Poor

9. IF Weight Egg $=$ Heavy and Light Egg $=$ Bad THEN Results $=$ Poor

In designing this system there are nine fuzzy rules that have been determined, each rule has different parameter categories from each other such as Table 2.

Table 2. Membership Set Fuzzy Logic

\begin{tabular}{cccc} 
& Nice & Medium & Bad \\
\hline Small & Good & Good & Poor \\
Normal & Good & Good & Poor \\
Heavy & Good & Poor & Poor \\
\hline
\end{tabular}

In this paper, there are many hardware and specifications used by system implementations. Table 3 shows the hardware system specifications. Besides the hardware used, the software to support the research is as below specifications: Windows Operating System 10, Arduino IDE Tools and NodeMCU, Firebase. 
Table 3. Hardware System Specifications

\begin{tabular}{ccl}
\hline Hardware & Hardware Type & \multicolumn{2}{l}{ System Hardware Functionalities } \\
\hline Microcontroller & NodeMCU ESP8266 & System control device and as \\
Microcontroller & sending data via Wifi. \\
Light Sensor & LDR & As transmitting sensors. \\
Weight Sensor & Loadcell & As a light detector \\
Counter & IR Infrared & As a heavy detector. \\
Actuator & Servo & As counting eggs. \\
\hline
\end{tabular}

\section{Results and Discussion}

\subsection{Egg Quality Detection System Testing Results}

After the system has been completed, the next step is to test the system. This test aims to find out how well the system has been made, namely by ensuring that input will provide results that are in accordance with the needs and aim to determine the performance of the system.

In testing the sensors the researchers observed the performance of sensor functionality. The sensor contained in the system detects egg quality consisting of a light sensor (LDR), a heavy sensor (loadcell) and an infrared sensor. Observation of this test produces the performance possessed by the sensors contained in Figure 7 and Figure 8 . Test results are processed and then produce output. Testing without using the Fuzzy logic method and get the results as in Table 4.

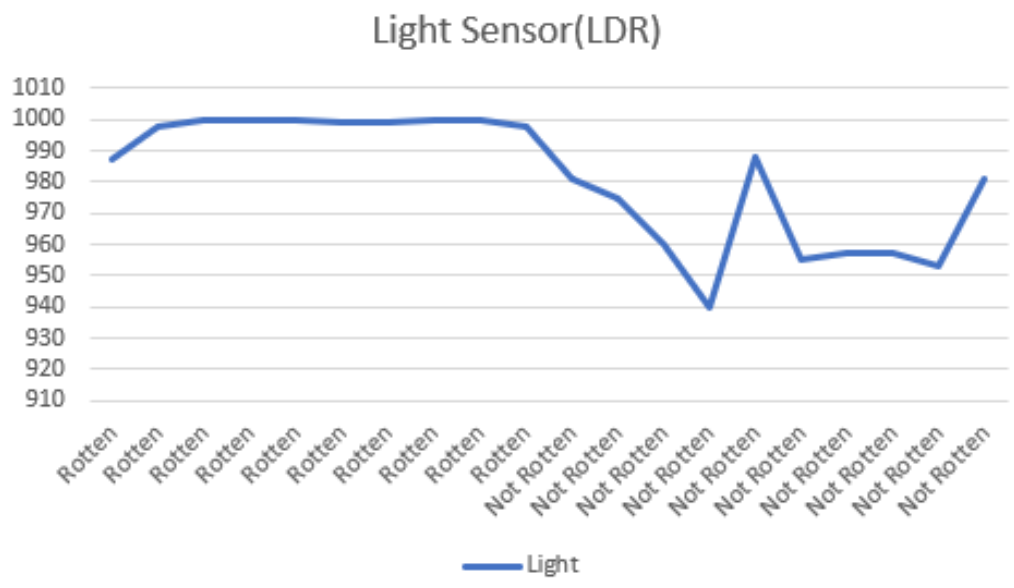

Figure 7. LDR Light Sensors

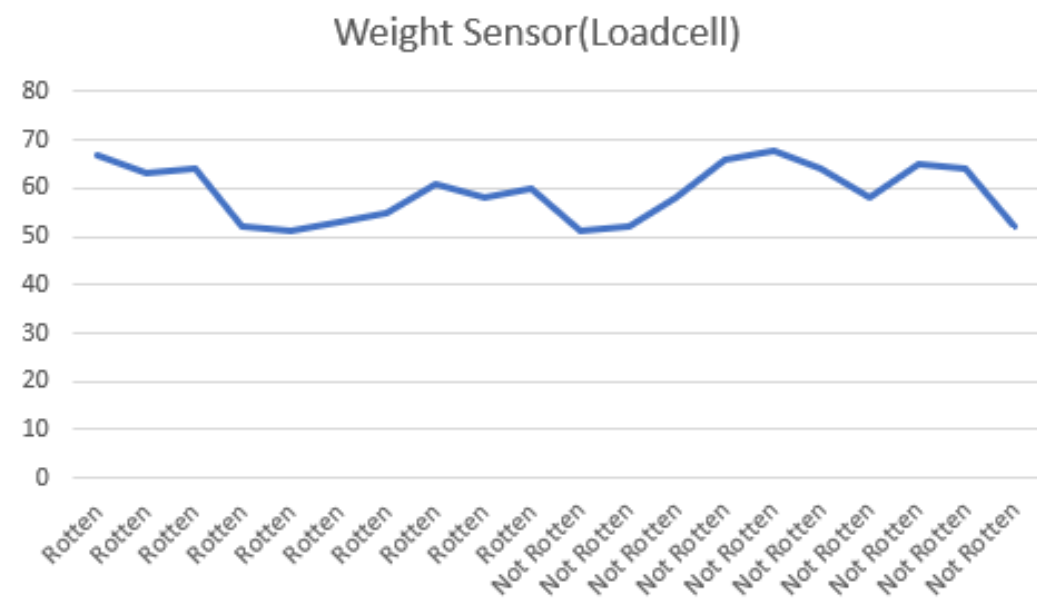

Figure 8. Loadcell Results Weight Sensors

The results of detection using 10 good eggs and 10 rotten eggs without using fuzzy logic methods such as Table 4.

(C) 2019 The Authors. Published by Universitas Muhammadiyah Malang

This is an open access article under the CC BY SA license. (https://creativecommons.org/licenses/by-sa/4.0/) 

Table 4. Output Results Without Using Fuzzy Logic

\begin{tabular}{ccccc}
\hline No & Egg & Weight $(\mathrm{g})$ & Light & Fuzzy Logic Results \\
\hline 1 & Rotten & 62 & 980 & Poor \\
2 & Rotten & 65 & 983 & Poor \\
3 & Rotten & 56 & 984 & Poor \\
4 & Rotten & 59 & 983 & Poor \\
5 & Rotten & 52 & 1010 & Poor \\
6 & Rotten & 64 & 1006 & Poor \\
7 & Rotten & 65 & 1013 & Poor \\
8 & Rotten & 54 & 1011 & Poor \\
9 & Rotten & 51 & 1015 & Poor \\
10 & Rotten & 58 & 1015 & Poor \\
11 & Not Rotten & 50 & 914 & Good \\
12 & Not Rotten & 60 & 915 & Good \\
13 & Not Rotten & 63 & 921 & Poor \\
14 & Not Rotten & 63 & 915 & Poor \\
15 & Not Rotten & 54 & 940 & Good \\
16 & Not Rotten & 65 & 956 & Poor \\
17 & Not Rotten & 50 & 905 & Good \\
18 & Not Rotten & 65 & 936 & Poor \\
19 & Not Rotten & 67 & 943 & Poor \\
20 & Not Rotten & 57 & 944 & Good \\
\hline
\end{tabular}

Egg placement without using the fuzzy Logic method to find out the results of the determination, the following Equation 1 are the results of the calculation.

Incorrect Data $=5$

True Data $=15$

Amount of Data $=20$

$$
\begin{aligned}
\% \text { Accuracy } & =\frac{\text { (Amount of Data) }-(\text { Incorrect Data) }}{(\text { Amount of Data })} \times 100 \% \\
& =\frac{20-5}{20} \times 100 \%=75 \%
\end{aligned}
$$

Egg detection without using the fuzzy logic method there are 15 egg conditions which are correct and there are 5 incorrect egg conditions, from the results it can be taken the value of accuracy of the data is $75 \%$.

\subsection{Fuzzy Logic Test Results on the Egg Quality Detection System}

The test results obtained on the detection of egg quality using the fuzzy logic method of 20 eggs will be detected and a decision will be made whether the eggs are good or poor from the defuzification value. The results using this fuzzy logic method can be seen in Table 5 .

Table 5. Output Results Using Fuzzy Logic

\begin{tabular}{cccccc}
\hline No & Egg & Weight $(\mathrm{g})$ & Light & Defuzzification & Fuzzy Logic Results \\
\hline 1 & Rotten & 67 & 987 & 72.92 & Poor \\
2 & Rotten & 63 & 998 & 72.14 & Poor \\
3 & Rotten & 64 & 1000 & 72.92 & Poor \\
4 & Rotten & 52 & 1000 & 63.65 & Poor \\
5 & Rotten & 51 & 1000 & 63.65 & Poor \\
6 & Rotten & 53 & 999 & 72.14 & Poor \\
7 & Rotten & 55 & 999 & 66.80 & Poor \\
8 & Rotten & 61 & 1000 & 65.70 & Poor \\
9 & Rotten & 58 & 1000 & 70.36 & Poor \\
10 & Rotten & 60 & 998 & 66.80 & Poor \\
11 & Not Rotten & 51 & 981 & 27 & Good \\
12 & Not Rotten & 52 & 975 & 27.08 & Good \\
\hline
\end{tabular}

Cite: Mahesa, I., Putrada, A. G., \& Abdurohman, M. (2019). Egg Quality Detection System Using Fuzzy Logic Method. Kinetik: Game Technology, Information System, Computer Network, Computing, Electronics, and Control, 4(3). Kinetik: Game Technology, Information System, Computer Network, Computing, Electronics, and Control, 4(3). doi:http://dx.doi.org/10.22219/kinetik.v4i3.839 


$\begin{array}{llllll}13 & \text { Not Rotten } & 58 & 960 & 27.08 & \text { Good } \\ 14 & \text { Not Rotten } & 66 & 940 & 28.71 & \text { Good } \\ 15 & \text { Not Rotten } & 68 & 988 & 66.8 & \text { Poor } \\ 16 & \text { Not Rotten } & 64 & 955 & 27.86 & \text { Good } \\ 17 & \text { Not Rotten } & 58 & 957 & 28.71 & \text { Good } \\ 18 & \text { Not Rotten } & 65 & 957 & 30.62 & \text { Good } \\ 19 & \text { Not Rotten } & 64 & 953 & 27.86 & \text { Good } \\ 20 & \text { Not Rotten } & 52 & 981 & 45.98 & \text { Good }\end{array}$

Placement of eggs using the fuzzy logic method to find out the results of the determination, the following Equation 2 are the results of the calculation

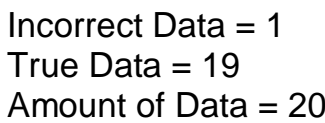

$$
\begin{aligned}
\% \text { Accuracy } & =\frac{(\text { Amount of Data })-(\text { Incorrect Data) }}{(\text { Amount of Data })} X 100 \% \\
& =\frac{20-1}{20} \times 100 \%=95 \%
\end{aligned}
$$

Egg detection using the fuzzy logic method there are 19 conditions for the eggs that are the correct result and there is 1 wrong egg condition, from the results it can be taken the value of accuracy of the data is only $95 \%$ compared without using the fuzzy logic method

\section{Conclusion}

Based on testing using 20 data from 20 eggs, the results of testing using the fuzzy logic method in the microcontroller get an accuracy rate of $95 \%$, whereas if not using the fuzzy logic method only get an accuracy rate of $75 \%$. So it can be concluded that the system built using the fuzzy logic method can reduce the ambiguity of manual egg checking and get an increase in accuracy of $20 \%$.

\section{References}

[1] S. Landep, "Pengertian Telur Lengkap Beserta Jenis, Cara Memilih, Manfaat dan Penyimpanannya," watonsinau.work

[2] M. Gong, X. Liu, X. Zhang, L. Chai and C. Hu, "Research On Detection Method For Egg Quality," in 2010 Seventh International Conference on Fuzzy Systems and Knowledge Discovery, Yantai, Aug Pp. 716-719, 2010. https://doi.org/10.1109/FSKD.2010.5569385

[3] N. Jazil, A. Hintono and S. Mulyani, "Penurunan Kualitas Telur Ayam Ras Dengan Intensitas Warna Coklat Kerabang Berbeda Selama Penyimpanan," Jurnal Aplikasi Teknologi Pangan, Vol. 2, No. 2, 2013.

[4] S. P. Hirokoa, T. Kurtinib and Riyanti, "The Effect of Storage Duration and Eggshell Color of Purebred-Chicken Egg to The Albumen Index, Yolk Index, and Egg's Ph," Vol. 2, 2014

[5] N. B. Suharyanto, C. K. N. Sulaiman, I. I. Zebua, and Arief, "Physical Quality, Microbiology, and Organoleptic of Egg Around IPB Campus, Dramaga, Bogor," https://doi.org/10.29244/jipthp.4.2.275-279

[6] W. Fang, T. Zuojun, C. Fei and W. Youxian, "Detecting Cracks of Preserved Egg Based on Polarized Light," in 2013 5th International Conference on Intelligent Human-Machine Systems and Cybernetics, Pp. 66-69, August, 2013. https://doi.org/10.1109/IHMSC.2013.163

[7] M. Abdurohman, A. Herutomo, V. Suryani, A. Elmangoush and T. Magedanz, "Mobile tracking System Using OpenMTC Platform Based on Event Driven Method," 38th Annual IEEE Conference on Local Computer Networks - Workshops, Pp. 856-860, 2013. https://doi.org/10.1109/LCNW.2013.6758523

[8] X. F, T. L, Yang, W. L and V. A, "Editorial Internet of Things," International Journal of Communication Systems, No. 25 , Pp. 1101-1102, 2012.

[9] P. Besari, M. Abdurohman and A. Rakhmatsyah, "Application of M2M to Detect the Air Pollution," in Information and Communication Technology (IColCT), 2015 3rd International Conference, Pp. 304-309, May, 2015. https://doi.org/10.1109/IColCT.2015.7231441

[10] A. R. Wiratno and K. Hastuti, "Implementation of Firebase Realtime Database to track BRT Trans Semarang," Computer Science Departement, Universitas Dian Nuswantoro, Vol. 4, No. 2, 2017. https://doi.org/10.15294/sji.v4i2.10829

[11] A. A. Aldair, M. Mokayef and T. A. Rashid, "Design and Implementation of Intelligent Control System for Egg Incubator Based on loT Technology," in 2018 4th International Conference on Electrical, Electronics and System Engineering (ICEESE), Pp. $49-54$, November, 2018. https://doi.org/10.1109/ICEESE.2018.8703539

[12] Y. Tanaka, "An Overview of Fuzzy Logic," in Proceedings of WESCON '93, Pp. $446-450, \quad$ September, 1993. https://doi.org/10.1109/WESCON.1993.488475

[13] Y. Dote, "Introduction To Fuzzy Logic," in Proceedings of IECON '95 - 21st Annual Conference on IEEE Industrial Electronics, Pp. 50-56, November 1995. https://doi.org/10.1109/IECON.1995.483332

[14] C. C. LEE, "Fuzzy Logic in Control System: Fuzzy Logic Controller-Part I," IEEE Transactions on Systems, Man, and Cybernetics, vol. 20, Pp. 404-418, April, 1990. https://doi.org/10.1109/21.52551

[15] M. Djunaidi, E. Setiawan and F. W. Andista, "Penentuan Jumlah Produksi Dengan Aplikasi Metode Fuzzy - MAMDANI," Jurnal IImiah Teknik Industri, Vol. 2, 2011. https://doi.org/10.23917/jiti.v4i2.1368

[16] M. Sumitre and R. Kurniawan, "Rancang Bangun Sistem Pendukung Keputusan Seleksi Penerimaan Tenaga Pengajar Dengan Metode Fuzzy Inference System (FIS) Mamdani," Jurnal Informatika, Vol. 14, 2014

[17] S. SUPATMI, "Pengaruh Sensor LDR Terhadap Pengontrolan Lampu," Jurnal Majalah IImiah Unikom, Vol. 8, No. 2, Pp. 175-180, May 2011.

(C) 2019 The Authors. Published by Universitas Muhammadiyah Malang

This is an open access article under the CC BY SA license. (https://creativecommons.org/licenses/by-sa/4.0/) 
[18] P. M. Manege, E. K. Allo and Bahrun, "Rancang Bangun Timbangan Digital Dengan Kapasitas 20Kg Berbasis Microcontroller ATMega8535," E-Journal Teknik Elektro dan Komputer, Vol. 6, No. 2301-8402, 2017. https://doi.org/10.35793/jtek.6.1.2017.16123

[19] D. Christover, A. . Y. P. T.S., J. A. P. S.T and M. . M. Yusup, "Rancang Bangun Alat Pendeteksi Kebusukan Telur Menggunakan Metode Fuzzy Logic Berbasis Mikrokontroler Arduino Nano 328," Jurnal Sains Terapan, Vol. 5, No. 1, 2019. https://doi.org/10.32487/jst.v5i1.584

[20] P. D. W. Ayu and G. A. Pradipta, "Egg's Diameter Detection Using Fuzzy C-Means and Iterative Random Hough Transform," in 2017 1st International Conference on Informatics and Computational Sciences (ICICOS), Pp. 53-58, November 2017. https://doi.org/10.1109/ICICOS.2017.8276337 
